Journal of Law \& Social Studies (JLSS)

Volume 3, Issue 2, pp 93-103

www.advancelrf.org

\title{
The Role of Islamic Law in Convergence to Western Corporate Governance Features in Pakistan
}

\author{
Dr. Imtiaz Ahmed Khan \\ Chairperson, Department of Law \\ University of Sahiwal \\ Email: imtiazahmad@uosahiwal.edu.pk
}

\begin{abstract}
This article examines the role of Islamic Law in convergence to western corporate governance features in Pakistan. The recent financial crisis in the world highlighted the importance of good corporate governance features. This phenomenon highlighted the possibility of adopting an alternative to conventional financial system in Pakistan. Islamic finance has shown its presence in the wake of financial crisis in the world. Therefore, this articles analyses, in comparative perspective, the Islamic financial system viz a viz conventional financial system. It further analyses the possibility of convergence of corporate governance mechanism, which is key for good governance in any financial system, in Pakistan. It concludes that Islamic Financial System may be adopted as alternative financial system as well as corporate governance mechanism may be converged to western corporate governance features in Pakistan. However, while doing so Islamic norms may act as a litmus test which may not be as problematic as it appears at first sight.
\end{abstract}

Keywords: $\quad$ Corporate Governance; Islamic Law; Islamic Finance; Pakistan; Convergence.

\section{Introduction}

The triumph of capitalism over its rival communism in the last part of previous century highlights the importance of capitalist financial system. The western world with its capitalist financial system has been ruling in the world since then. The concept of modern financial system developed in the capitalist countries was alien to classical Muslim jurists. However, the Islamic finance was very much in vogue in early period of Islam. Islam being a practical religion guides its subjects in each field especially in financial matters. In Islamic Finance the interest is not considered as legal and profitable activity which is basic difference between conventional western style of financial system and Islamic finance.

It is widely believed that Islamic finance prohibits all modern western style of financial transactions. However, this is only half of the story. Islam provides an alternative to debt and loan financing.

In recent financial crisis the excessive leveraging was one of the major causes. As Islamic finance discourages leveraging, therefore, financial experts, scholars and researches started researching an alternative financial system that may respond more appropriately in times of financial distress. Islamic finance has shown its presence against the backdrop of the recent financial crisis and urges scholars to provide an alternative. Recent industrialisation and globalisation have increased the process of convergence where one jurisdiction converges to other jurisdiction having better system. Therefore, there is possibility of convergence of one financial system with other having better features.

\section{Nature of the Islamic financial system}

Islam is a practical religion that guides its subjects in each field, including financial matters (Usmani, 2004). A basic difference between the conventional financial system and Islamic finance is the treatment of interest. The debt is not considered a legal, profitable economic activity under Islamic finance (Venardos, 2012). Conventional finance is 
based on interest-bearing transactions, whereas Islamic finance prohibits interest from personal as well as commercial loans. There is a misconception about Islamic finance that this system prohibits all modern transactions. This is only half of the story. Islam provides an alternative to debt and loan financing. It prohibits interest, uncertainty and immoral business activities. As far as interest is concerned, Islam regards it as exploitative and the circulation of money among the rich only. The Qur'an prohibits riba by providing a justification for its evil effects: it states that 'it [wealth] may not [merely] make a circuit between the wealthy among you' (Qur'än, 59:7). Interest is, in fact, earning money over money and this may provide opportunities to rich people to enhance their money without getting involved in real economic activities. The Islamic finance system is based on distributive justice, which means the distribution of wealth, goods and resources among the rich and the poor.

In addition to this, it prohibits certain businesses which it considers immoral, unethical or religiously prohibited, for example, gambling; the preparation of alcohol and its related products, and pork products; and pornography. The other difference between conventional finance and Islamic finance is uncertainty. Some financial transactions of conventional finance, such as the futures market, short selling and gambling businesses, are not allowed under Islamic finance on the basis of inherent uncertainty.

The Islamic financial system is characterized as based on ethics and morality. It prohibits risk-free return on finance (Her Majesty's Treasury [HMT], 2008). The prohibition on riba is one manifestation of this characteristic. Riba provides one party with an undue advantage over another; for instance, A gives a loan of US $\$ 100,000$ to B for two years with interest of $10 \%$ per year. B starts a business with US $\$ 150,000$ and suffers a loss of US $\$ 50,000$. B now has to return US $\$ 100,000$ to A as the capital return and US $\$ 20,000$ as interest. B is left with only US\$100,000 in business. This means that B has to pay US $\$ 20,000$ from other sources. In this situation, it will be an injustice against B. However, suppose B earns profit amounting to US $\$ 100,000$. B will pay US $\$ 120,000$ (US\$100,000 as capital and US\$20,000 as interest) to A and will retain US $\$ 80,000$ as profit for himself. B has earned profit of US\$80,000 with only a US\$50,000 investment, whereas A has earned US $\$ 20,000$ with a US\$100,000 investment. The profit ratio for B will be $160 \%$, whereas it is only $20 \%$ (in the form of interest) for A.

In this situation it is injustice against A. This is the main reason for the prohibition on interest (riba) as this may cause an injustice to both or one party. Islam prohibits interest as one may have an advantage without taking risk and sharing in profit and loss. Interest-bearing transaction may encourage the earning of money without taking part in actual economic activity. It, therefore, encourages equity financing. In equity financing there may be less injustice against any one or more parties as all will share in the profit and loss. Islamic finance provides different techniques for carrying on businesses that may be used as alternatives to conventional financing. Modern Muslim and non-Muslim jurists are trying to provide alternatives to the conventional finance system. The provisions of Shariah-compliant products as an alternative to conventional financial products are the main features of recent research in Islamic finance. Modern jurists are trying to synchronize Islamic finance with conventional finance. Synthesis is possible between Islamic finance and conventional finance to a certain extent, except for interest, uncertainty, and certain businesses, which are not allowed under Islamic law.

\section{Equity versus debt financing}

Islamic finance deals with both equity and debt finance in different ways. Islamic finance encourages equity financing and discourages debt financing. The nature of debt financing is contractual. This is more secured financing in which the creditors receive predetermined amounts in the form of interest and capital irrespective of any profit gained by the debtor in the business. This amount is to be paid within the framework determined in the contract. If a debtor fails to pay interest or return capital, then the creditor has the right to enforce this under the terms of the contract as well as under different laws. As the paying of interest or capital becomes difficult for the debtor in the case of financial difficulty, the nature of debt financing is, therefore, a kind of exploitation in most cases. The creditor has the right of reorganization and liquidation in the case of failure to pay interest or capital. However, the nature of the equity investment is participation in the business. The investor shares in the profit, which is not predetermined. The investor gets a return on investment only when there is a profit in the business. Therefore, there is less of an element of exploitation in the equity investment. The investor has the right to participate in the management, except in those cases where he or she relinquishes this right by acquiring shares without voting rights.

The problem with debt financing is that more debt financing provides the firm with leverage that may be beneficial to it up to a certain level but this leverage may be dangerous when it goes beyond certain limits. This means enhanced 
leverage is a risky venture (Handschin, 2012). The recent global financial crises are associated with, inter alia, bad governance and unbridled debt financing by banks. The debt ratio was increased and debtors were unable to repay their debt. There was not enough equity which could have avoided the crisis. This caused huge financial uncertainty and resulted in a crisis (Ross, Westerfield, \& Jordan, 2010).

Debt financing has structural advantages over equity financing as debt is given more security and the right to recover a loan as per a contract. Equity financing is, however, not secure for individual investors but as far as the corporate structure is concerned, it avoids potential corporate risks. Equity financing requires some assurance to avoid individual risk. This risk can be minimized when there is good governance associated with equity financing. To share the burden of risk, it is necessary that equity holders be given decision-making power and management rights; in other words, the nature of equity financing is to take part in management by contesting the election of directors or voting to elect directors, to make major decisions, and to share in profit and loss. More equity financing in firms will trigger more good corporate governance. As Islamic finance encourages equity, good corporate governance is, therefore, exactly in accordance with the spirit of Islamic finance.

\section{Evolution of Islamic finance}

A presumption about Islamic finance is that it was introduced in the early ages of Islam and that it was not a flexible system that would cater to the needs of modern times. This is an incorrect assumption. Islamic finance is currently still relevant and is ever developing. The role of Muslim scholars is very important in this regard. The new products introduced through conventional finance can be checked in the light of Islamic law due to the flexibility available in Islamic law. Modern scholars have worked on Islamic finance and have discussed its feasibility according to modern needs and requirements. Islamic finance was central in religious teachings for two reasons. First, religion is integral to the day-to-day life of Muslims and in their financial matters. Second, the Prophet Muhammad (peace be unto him) was himself a merchant; therefore, financial dealings were central to the life of the Prophet. The recent focus on Islamic finance caught the attention of financial experts for two reasons. First, there is emphasis on Islamic finance in the Muslim world, which forms a substantial part of the world economy. This phenomenon started in Egypt in 1963 through the introduction of the Mit Ghamr savings project, a social banking initiative (HMT, 2008) and later developments such as the establishment of the first Islamic bank in the mid-1970s. Second, when there was a recession in the world and conventional finance failed to respond appropriately (Warde, 2012).

In modern times in the Muslim world, Pakistan was the first country that declared that it would Islamize all its banks. It did so in 1979. Iran and Sudan followed, and in 1983 they declared that they would Islamize their banks. Malaysia, instead, introduced a parallel banking system in 1983 (Warde, 2012). In recent times Islamic finance has been the most dynamic and fastest-developing financial system. Both Muslim and non-Muslim countries have introduced it in their financial system. The focus is on introducing this system parallel to the existing financial system (Von Pock, 2007). The introduction of two parallel financial systems may have some legal and regulatory barriers as both conventional and Islamic finance have different natures and, to some extent, are rival systems. This rivalry is based on two important issues: (1) riba ('interest') and (2) gharar ('uncertainty'). Islam provides an alternative to interest by emphasising profit and the sharing of business activities. It discourages loans but allows them under conditions of necessity and on humanitarian grounds but without interest. It also prohibits uncertain transactions. Both conventional finance and Islamic finance may not be a major problem as both can be synchronized and implemented on the basis of the nature of the products involved. However, this requires the state's commitment to implementing Islamic finance in its true spirit.

\section{Islamic finance as an alternative financial system}

The recent financial crisis, which was linked to excessive leveraging, highlighted the importance of an alternative financial system that may respond more appropriately in times of financial distress (Venardos, 2010). Islamic finance prohibits excessive leveraging and focuses on trust building. It focuses more on the ethical realm of business than a sole financial aspect which is dominant in conventional finance (Rasul, 2010). Islamic finance has shown its presence against the backdrop of the recent financial crisis and urges scholars to provide an alternative. One advantage of Islamic finance is that it is an emerging system that has not yet been utilized in modern finance (Von Pock, 2007).

The Islamic financial system is different from capitalism and communism. Capitalism is a market-based financial system that provides the freedom of having private ownership, whereas communism provides a controlled economy with the state controlling all economic activities and restricting private ownership by individuals. Capitalism 
reconfigures existing economic and social arrangements; develops according to market needs; and focuses on individual self-interest and privileged rational utility over traditional ethical norms (Crone, 2003). Such an ideology was alien to Islam (Kuran, 2011). Islamic finance is based on a different ideology. Its thrust is on ethics and morality. It restricts the free flow of wealth in a few hands (Nyazee, 2007), and provides detailed guidelines in the financial matters of its subjects. It prohibits interest-bearing and uncertain transactions. It encourages equity-based financing, sale and leasing contracts (Warde, 2012). The prohibition on interest-bearing transactions is a major difference between capitalism and Islamic finance (Venardos, 2012). Islamic finance requires real asset-based transactions (Usmani, 1999), and links financial transactions to the real economy, which is governed by the principle of sharing in profit and loss.

It prohibits interest (riba) and uncertainty (gharrar), and encourages equity financing backed by real assets (Warde, 2012). Capitalism emphasizes individual rights which allow the unbridled accumulation of wealth, whereas Islamic finance focuses on the welfare of the whole of society which does not allow the exploitation of others (Venardos, 2012). Another major difference includes the prohibition on excessive leveraging and imprudent risk taking by Islamic finance. Similarly, paper money is not considered a commodity in Islamic finance. It is considered a medium of exchange and therefore cannot be utilized to increase purchasing power without involving a commodity and a productive activity that is beneficial to society (Venardos, 2010).

The failure of communism in the 1990s and the economic meltdown in last part of the twentieth century and the early part of the twenty-first century has highlighted the importance of an alternate financial system in the world. Islamic finance received attention in the recessions. It has been the most dynamic and fastest-growing economic system in the recent past. There has been extensive academic research on Islamic finance both in the East and West (Von Pock, 2007). Products based on Islamic finance are being introduced not only in the Muslim world, but also in non-Islamic countries such as the UK ${ }^{1}$ and the US. ${ }^{2}$ Islamic finance may not be an ideal financial system for the West as it is not familiar with such a system and it is considered directly related to religion. However, Islamic finance is not restricted to Muslims. It is open to everyone, including non-Muslims. The choice is with the consumers based on pure competition. If Islamic finance provides better options and products to investors and consumers, they will derive an advantage from it.

The new economic world scenario is based on pure efficiency and competition, and religion has a very limited role to play, at least in the Western world. Ethics may also be another reason why non-Muslims would be attracted to Islamic products. Ethical finance, such as the prohibition on financing in businesses relating to alcohol, gambling and pornography may also attract non-Muslim who have religious beliefs in this regard (HMT, 2008). However, Islamic financial transactions may be undertaken on a purely religious basis in the Muslim world in general and Pakistan ${ }^{3}$ in particular where religion dominates in the social, political and economic life of the masses.

Pakistan is a leading country in the Muslim world when it comes to Islamizing its economy (Rasul, 2010). It was a difficult task for Pakistan as there was no successful model to follow (Masood, 2006). Nevertheless, it started Islamizing its economy through the introduction of Shariah-compliant products in the early 1980s. The first step was to change the banking laws through change in the Banking Companies Ordinance 1962 and introducing profit and sharing accounts. The other major steps included permission to do business through the mudarabah form of business. The introduction of the Mudarabah Companies and Mudarabah ('Flotation and Control') Ordinance 1984 allowed the establishment of Islamic financial institutions that allowed the conduct of business through the mudarabah form of business. In 1991 the government promulgated the Enforcement of Shariah Act, 1991 to Islamize the economy and

\footnotetext{
${ }^{1}$ There are 4.13 million Muslim in the UK, which is $6.3 \%$ of the total population by the 2016 reported by the Pew Forum on religion and public life, a US-based organisation. See Pew Forum report 'Database: Religious Composition by Countries in Numbers and Percentage', available at < http://www.pewforum.org/2017/11/29/europes-growing-muslim-population/ > Accessed 05.11.2018. ${ }^{2}$ There are 3.45 million Muslim in the US, which is $1.1 \%$ of the total population by the year 2017 reported by the Pew Forum on religion and public life, a US-based organisation. See Pew Forum report on 'Database: Religious Composition by Countries in Numbers and Percentage', available at $<$ http://www.pewresearch.org/facttank/2017/08/09/muslims-and-islam-key-findings-in-the-u-s-and-around-the-world/ > Accessed 05.11.2018.

${ }^{3}$ Pakistan is a Muslim country where Islam is the state religion enshrined in the constitution, which reflects pure public sentiments about Islam. Pakistan has a population of approximately 20.77 million, with $97 \%$ Muslims residing in Pakistan as per the Population Census Organisation, Government of Pakistan website 2017.
} 
industry. This paved the way for the introduction of Islamic mutual funds, Islamic insurance (takaful), leasing (ijarah) and licensing of Islamic commercial banks (Rasul, 2010).

The breakthrough in this regard was the decision of the Shariah Appellate Bench of the Supreme Court in 1991 that declared riba against the injunctions of Islam and set June 2001 as the deadline for the elimination of riba from the economy. The government filed a review petition. The decision was stayed and is still pending. This shows lack of interest both at government and institutional level to eliminate riba, and to Islamize the economy. This is a dilemma for the government. On the one hand, it has shown efforts to Islamize the economy, and, on the other hand, it is not willing to implement a decision prohibiting riba, which is a major cause for concern in Islamic finance. There may be three reasons for this decision. First, there have been frequent changes in governments in Pakistan.

Sometimes the leftist and sometimes the rightist dominate the political scenario. Pure Islamic parties also have a say in each government. The successive governments may not have the intention to implement pure Islamic finance; rather these parties may have made provision for it in their manifesto to obtain political advantages by exploiting the sentiments of the people to get their votes. Second, in the new era of the global economy it may not be feasible to prohibit riba unilaterally when countries have debts of billions of dollars brought about by global forces. However, the elimination of riba at the domestic level may not be a major problem. This needs some kind of commitment from the government and financial institutions. Third, lack of legal, regulatory and institutional infrastructure may be another cause for the failure in implementing the Supreme Court decision to Islamize the economy (Masood, 2006). The decision cannot be implemented without proper homework.

In Pakistan mudarabah business flourished to some extent but the way in which it was operated was not purely Islamic (Vogel \& Hayes, 1998). This disappointed the people who intended to do business in an Islamic way and for those with an awareness of Islamic finance. Corruption, bad governance, scarcity of a regulatory framework and lack of human resources were the main barriers to the success of Islamic finance in Pakistan. The intentions of most of the entrepreneurs were not to do business in accordance with the Shariah but they started businesses just to enjoy the tax incentives provided by the government for mudarabah businesses and to exploit general public sentiments. It was an easy way to get finance from the general public in the name of Islam (Rasul, 2010). All this caused the failure of mudarabah business in Pakistan and shed doubts on Islamic finance flourishing in Pakistan. Islamic finance can be successful only if a good corporate governance mechanism is established. This would require the government, regulators, and other institutions to take several steps.

In Pakistan Islamic banking business is not much different from the conventional system. It amounts to a change of nomenclature and most of the transactions conducted by the banks in leasing and murabahah were viewed as suspicious by scholars on the grounds that the objective of these transactions was to defeat the Islamic prohibitions of riba (Mansuri, 2005). In reality, these transactions were more or less like interest-bearing transactions. Islamic finance can be successful only if there are serious efforts and change in mind set at government level as well as entrepreneur level.

Failure of mudarabah business triggered regulator's attention to improve mudarabah business in Pakistan. In 2008 the SECP and Mudarabah Association of Pakistan conducted research to obtain the Shariah board of mudarabah's approval for the new Shariah-compliant products to enhance the scope of mudarabah business. They approved 12 products $^{4}$ to enhance the scope of mudarabah and other Shariah-complaint businesses in Pakistan (Rasul, 2010). This is another effort at institutional level to Islamize the economy. The question is whether it will change the existing image of the failed mudarabah business introduced in the early 1990s?

The few efforts by the government to Islamize the economy were just the start of a long journey. More needs to be done in this regard. It may not be useful merely to declare something Islamic or un-Islamic. First there is a need to provide an alternative to existing financial products. The existing system cannot be changed overnight. Scholars of Islamic law should try to synchronize existing financial products with Islamic norms keeping in mind the basic precepts of Islam. Different schools of law in the Muslim community have different interpretations of sources of Islamic law, which may create divergence. This may not be a major problem. Divergence can be converted into

\footnotetext{
${ }^{4}$ These businesses include leasing (ijarah), progress financing (istisna), partnership or company (mudarabah), musawamah, partnership or company (muharakah), cost-plus financing (murabaha), trade finance (salam), diminishing musharakah, syndicate mudarabah, syndicate musharakah, continued funding system (Islamic CFS murabahah), Islamic bonds (sukuk).
} 
convergence, but this needs some kind of flexibility in the rules of interpretation to the extent that the interpretation of other schools that is appropriate is adopted and that modern financial products be accepted rather than rejected. Secondly, the scarcity of human resources is another problem in this regard. Some institutions are engaged in Islamic research, but they are not enough to cater for the needs of Islamic finance on a larger scale.

There is a need to encourage Islamic research at institutional level that can produce scholars who are acquainted with both the modern form of business and the Islamic form of business. Thirdly, corporate governance needs to be strengthened. An inefficient corporate governance system is a major problem in any kind of business. In Pakistan bad governance is a barrier to the healthy growth of the market in general and the economy in particular. There is a need to improve the governance mechanism in Pakistan. Enforcement is a key to good governance. The judiciary, market and regulatory framework need to be improved in order to enhance enforceability in the corporate sector. As far as Islamic finance is concerned, as it encourages equity financing and prohibits interest-bearing transactions, good corporate governance will be a key to its success.

Some efforts have also been made at international level. The establishment of the Islamic Financial Services Board (IFSB) in 2002 was a major step towards this development. It started its operation from 10 March 2003. The board sets standards for regulatory and supervisory agencies involved in Islamic finance, including banking, capital markets and insurance. Its objectives are to promote the development of Islamic industry and to recommend new or adopt existing international standards after adaptation to injunctions of the Shariah. The board also guides regulatory agencies for effective supervision and regulations of institutions offering Islamic products. It plays a liaison role among institutions involved in standard setting. So far, the board has issued 19 standards, guiding principles and technical notes for the Islamic financial services industry, including guiding principles on corporate governance for institutions offering only Islamic financial services (excluding Islamic insurance (takaful) institutions and Islamic mutual funds).

It has issued separate guidelines for insurance and mutual funds (http://www.ifsb.org/). The IFSB takes guidance from other institutions involved in standard setting for banking, finance and governance, for instance, the IFSB has considered standards issued by the Basel Committee on Banking Supervision, and the International Organization for Securities Cooperation for investment and securities markets in order to set its own standards for Islamic banking and finance (Venardos, 2010) but subject to the condition that they are not against the Shariah. The IFSB issues guiding principles and they are subject to approval at national level. As these principles do not have binding force, the possibility of divergence at international level exists.

The International Islamic Fiqh Academy (IIFA) is a constituent part of the Organization of Islamic Cooperation (OIC). The objective of the academy is to find solutions to contemporary problems according to the Shariah and to guide the Muslim community to conduct their life according to the Shariah at individual, social and international level. The academy is involved in research in Islamic law and issues Islamic legal opinions (fatwas) for guidance to the Muslim community. The scope of research and opinion includes Islamic finance so that the Muslim community could convert their conventional finance to Islamic finance. The rulings of IIFA are guiding principles only and do not have any kind of binding force. This may also lead to divergence in the Muslim world.

The commonly approved Shariah products and market can facilitate convergence in Islamic finance at international level in the Muslim world. This could be achieved when there is consensus between Islamic scholars themselves. Once the Islamic form of business is accepted and implemented at national level, consensus at global level would be required. Consensus in OIC countries that is commensurate, at least to some extent, with EU efforts is also needed.

It is widely accepted that Islamic finance is not immune to financial crises. However, an important question is the extent to which financial crises may impact on Islamic finance. Venardos (2010) warns that Islamic finance may be affected indirectly in any turmoil in the world. According to him, the slower economic growth may affect real estate and asset finance. He further warns that reduction in prices of real estate may indirectly affect Islamic financial institutions as their business activities are directly connected to real assets. According to him, this may decrease their assets and affect business. However, this observation should be hedged with other aspects of Islamic finance. Islamic finance is not entirely related to real assets. Islamic finance focuses on ethical business. It prohibits interest-bearing transaction, excessive leveraging and avoiding uncertainty. It encourages sharing in profit and losses and carry-on business based on mutual trust and confidence. 
Venardos (2010) is also concerned that Islamic financial institutions may pursue aggressive speculative investment strategies with higher risk and higher expected returns in economic stress without adhering to fundamental and sound risk management standards. The IFSB is working towards providing guidelines to avoid such situations. These concerns highlight the importance of good corporate governance strategies to avoid such situations. Another important point in this regard is that Islamic finance does not encourage speculative business strategies. Corporate governance under Islamic finance may not encourage strategies on the part of the managers that are highly speculative irrespective of the quantum of profit they may yield.

Whether Islamic finance will be effective and can provide an alternative financial system at international level in general and Pakistan in particular is a difficult and premature question. However, the principles of Islamic finance cannot be ignored as they focus on ethical business and preach social responsibility (Rasul, 2010). Islamic finance has gained the attention of the world after the recent global financial crisis. The Muslim world has started converting its conventional finance to Islamic finance. Recent research in the Muslim world in general and the Western world in particular shows that Islamic finance has made its presence known and may be considered an alternative financial system. This is a difficult task and requires extensive research in the field. As far as the recent financial crisis is concerned, it is widely accepted that as Islamic finance relies on asset-backed financing, it might have responded more appropriately than capitalism (Warde, 2012).

No doubt, this system is gaining importance in the Muslim world based on religion, but it has potential due to its very nature. However, it can be considered in the non-Muslim world only when it is devised beyond the religious aspect and shows its strength as a better financial system than the conventional financial system. It can be introduced in the Islamic world generally and in Pakistan in particular. Once it shows its acceptance and success in the Muslim world, the non-Muslim world may take advantage of it to avoid uncertainty inherent in conventional finance. Globalization has integrated markets and survival of any system depends upon the provision of competitive products (Vogel \& Hayes, 1998). Therefore, Islamic finance can provide an alternative only when gaps in Islamic finance are filled in order to compete in the global economy. This is an uphill task for researchers in general and jurists in particular.

\section{Islamic finance and stock market indices}

Muslim and some non-Muslim countries have introduced stock market indices in their jurisdictions. In non-Muslim countries this may not be based on its success or pure competition, but rather to attract Muslim customers residing in their jurisdiction (Franzoni, 2018), for example, the Dow Jones Islamic Market Index in Bahrain, the FTSE Global Islamic Index in the UK (Von Pock, 2007) and the Shariah-compliant index of the KSE in Pakistan.

At present there are 112 Shariah-compliant companies on the KSE (http://kse.net.pk/). The ratio of these companies to total number of companies is low. This shows that Islamic finance has not gained its footing in Pakistan. Bad governance, accompanied by a lack of legal, regulatory and institutional infrastructure, is a major problem in the flourishing of Islamic finance in Pakistan. Therefore, the improvement of the governance mechanism is essential for the success of companies involved in Islamic finance.

\section{Convergence to Islamic Finance and Corporate Governance within the Muslim World}

The recent phenomenon of utilizing Islamic finance as an alternative or parallel to the conventional financial system in Muslim countries in general and Pakistan in particular has raised different issues. There is a possibility that different countries may have different modes of financing which may conflict with each other as far as their forms and conditions are concerned. This premise is based on the very nature of Islamic law. Though Islamic law provides a degree of flexibility to cope with modern needs and requirements, the problem with Islamic law is that the Qur'an provides general principles only. The book is not composed of detailed rules. These principles were practised and explained by the Prophet Muhammad (peace be upon him) and companions. The other problem was the compilation of the Sunnah of the Prophet quite a long period after his death which allowed fabrication of the Sunnah. This created differences of opinion among Muslim jurists regarding acceptance and the degree of force that such Sunnah may exert on the creation of rules. 
The other problem is the interpretational rules of different sects of Muslim jurists. Islamic law provides jurists with leverage to explain modern problems in the light of existing principles. The sources of Islamic law other than the Qur'ann and Sunnah provide this leverage to interpret primary sources. This may lead to different interpretations which, in turn, may lead to different forms of businesses and governance mechanisms that may cause barriers to convergence to a single model in the Muslim world.

Globalization has triggered convergence of different corporate governance norms due to the inter-related interests of the countries, competition and cross-border investment. This phenomenon raised enforcement issues in corporate governance. The Islamic world realizes this difficulty and established the IFSB in order to ensure common Shariahcompliant products and regulations. However, a rigid interpretation of the sources of Islamic law by jurists had been the main cause of concern which has led to divergence of fiqh within the Muslim world. This may create problem in the development of unique Shariah-compliant products, market and corporate governance.

Therefore, there is a need for jurists to show flexibility in interpreting sources of Islamic law. Modern jurists have developed techniques to overcome this difficulty. These techniques include but not limited to, 'choice and selection', 'amalgamation or patching', 'necessity' and 'ruses' (Ahmed, 2012). These may be utilized to redefine the figh according to modern requirements. This may help to unify different interpretations of Islamic law and converge to unique corporate governance and corporate finance, at least within the Muslim world. This will also help Pakistan to converge to Islamic finance in the Muslim world.

\section{Convergence to Western corporate governance}

There are basic differences between Islamic finance and Western financial systems (Alam et al, 2019). Islamic finance emphasizes ethical norms and focuses on the purposes of Islamic law both in the context of corporate law and corporate governance. It does see the interest of investors but looks beyond the sole interest of investors. It wants to achieve the objectives of society as a whole and to safeguard the religion as well. However, the Western model of corporate governance focuses on individual interests and tries to achieve what is demanded by the market (Istrefi, 2020). It does focus on society as far as business and corporate governance are concerned but that may not be the primary priority as against the individual interests in the businesses. ${ }^{5}$ Managers in the Western form of corporate governance may not be duty-bound to preserve religion which is the basic thrust of Islamic law. This disparity between Islamic finance and the Western financial system may be minimized provided the objectives are clearly defined and some level of flexibility is shown at least by the Muslim jurists in their interpretational rules.

In the context of Pakistan, it is important to synchronize existing Western forms of business practices, corporate law, corporate governance objectives and trading in shares with Islamic norms. The basic difference between the Western forms of business practices and Islamic finance is the prohibition on interest. As far as form of business is concerned, most conventional forms of business are very much Islamic, but a few are prohibited by Shariah, and must be avoided in order to create system that is in accordance with the Shariah; for instance, businesses of gambling, preparation of alcohol and pornography may be banned. Trading in stock exchanges is very much Islamic. However, trading in debts, debt securities, forward and future contracts, and short selling must be avoided. As far as corporate governance is concerned, the rights and the protection of investors are as important in Islam as they are in the Western form of corporate governance.

As far as good corporate governance is concerned, it is more important in Pakistan than in any other jurisdiction. Firstly, the prevailing bad governance requires improvement. Secondly, as the thrust of Islamic finance is on equity financing, good corporate governance will be important for Pakistan as the country moves towards Islamic finance. Thirdly, as Islamic finance is new to modern financing techniques, it has not developed investors' rights and their protection (Ahmed, 2012). The Western form of corporate governance has developed these rights and protection. As far as Pakistan is concerned, it inherited the British legal and regulatory system, therefore, Pakistani policymakers and legislature may benefit from the Western form of corporate governance in general and the UK system of corporate governance.

Islam has to play an important part in the corporate sector of Pakistan. Any future convergence to a Western form of corporate governance may be affected by Islamic injunctions. The barrier of Islamic finance to the Western form of corporate governance may not be as strong as it appears at first sight. Islamic law is also not as rigid as it appears. It

${ }^{5}$ This discussion excludes corporate social responsibility. 
has some inherent flexibility in its nature. Some sources and principles of Islamic law such as 'presumption of continuity', 'ruses' and 'necessity' may help to bridge the gaps between Islamic and Western forms of corporate governance. The Western form of corporate governance may be adopted in Pakistan after adaptation in the light of the above-mentioned principles and subject to the objectives of Islam highlighted in this chapter.

\section{Pakistan and Islamic Financial System}

Pakistan is an Islamic republic. The constitution prescribes Islam as the state religion. It is a practical religion which guides its subjects in all spheres of life, including financial matters. Globalization, competition and inter-related financial interests have stimulated convergence from more developed countries to less developed countries all over the world. Pakistan, being a developing county, has been the recipient of foreign governance features. As both conventional and Islamic financial systems have different objectives, convergence to a Western corporate governance feature in Pakistan has to pass the Islamic litmus test.

As far as convergence in corporate governance to international norms in Pakistan is concerned, there are two aspects involved. First is the unique convergence to Islamic finance and corporate governance within the Islamic world. This will also affect Pakistan. The evolution of different schools of thoughts within the Muslim world may lead to divergence in Islamic finance among Muslims. This divergence may be overcome but there is a need to show some kind of flexibility in interpretation by Muslim jurists. There are different techniques in Islamic law that can help to bridge the gap between different interpretational rules and to come to some consensus. Principles such as 'choice and selection' (iktiyar and takhayyur), 'amalgamation or patching' (talfiq), 'necessity' (darurah) and 'ruses' (hila) may be utilized to redefine the fiqh according to modern requirements. This may help to unify different interpretations of Islamic law, and converge to unique corporate governance and corporate finance, at least within the Muslim world. This will also help Pakistan to converge to the Muslim world's Islamic finance and corporate governance.

The second aspect is convergence to the Western model of corporate governance in Pakistan. Pakistan is an Islamic country but, being a former British colony, it has adopted the conventional financial system based on the British system. As Pakistan is an Islamic country and people's thrust was towards Islamizing its economy, the government took steps to do so. However, it has not been successful for different reasons such as bad governance; a weak enforcement mechanism; lack of human resources and state commitment; the absence of a legal and regulatory framework; and institutional incapacity. The problem with using Islamic finance in Pakistan is its utility in modern times as the same has not been used before. Furthermore, there is no successful model for Pakistan within the Muslim world. According to classical Muslim jurists, there is a stark difference between the conventional and Islamic financial systems as both have different objectives. Modern jurists are working on Islamic finance to make it an alternative financial system. These efforts of providing an alternative financial system may only be successful when gaps in Islamic finance are filled in order to compete in the global economy.

Globalization has forced convergence of different corporate governance features where survival of any system depends upon the provision of competitive products. In order to improve corporate governance in Pakistan, convergence to Western corporate governance features but within the limits prescribed by the Shariah is needed. Firstly, as an abrupt overnight change from the conventional to Islamic financial system is not feasible, the system needs to be changed through a pragmatic approach. Therefore, instead of changing the whole system, the existing system needs to be synchronized with the Islamic financial system. A synthesis is possible to the extent that Western governance features can be adopted that are not against the Shariah under the principle of 'presumption of continuity'. Secondly, the features that have defect may be restructured in a way that they are made compatible with Islamic finance. The Islamic method of 'ruses' (hila) may help to remove this defect. Thirdly, the features that have minor defects may be adopted under the principle of 'necessity' (darurah).

This whole process needs substantial research and flexibility on the part of Muslims jurists. The role of Muslim jurists will dominate the process.

\section{Conclusion}

The Islamic Financial System and conventional financial systems are considered as two rival systems but there is possibility of synthesis but there is a need to show flexibility in interpretational rules by the Muslim Scholars keeping 
in view the modern needs and requirements. Although some work has already been done by the modern Muslim scholars but there is a need to do more. Further, Islamic Financial System may be adopted as alternative financial system as well as corporate governance mechanism may be converged to Western corporate governance features in Pakistan. However, while doing so Islamic norms may act as a litmus test which may not be as problematic as it appears at first sight.

\section{REFERENCES}

Ahmed, H. (2012). Islamic Law, Investors' Rights and Corporate Finance. Journal of Corporate Law Studies, 12 (2) $367-392$.

Alam, M. K., Rahman, S. A., Mustafa, H., Shah, S. M., \& Rahman, M. M. (2019). An overview of corporate governance models in financial institutions. International Journal of Management and Sustainability, 8(4), 181-195.

Crone, P. (2003). Pre-Industrial Societies: Anatomy of the Pre-Modern World (2 ${ }^{\text {nd }}$ Ed.). Oxford, England: Oneworld.

Franzoni, S. (2018). Principles of Islamic Finance and Principles of Corporate Social Responsibility: What Convergence? Sustainability, 10(3), 637. MDPI AG. Retrieved from http://dx.doi.org/10.3390/su10030637

Her Majesty Treasury. (2008). The Development of Islamic Finance in the UK: The Government's Perspective. London, England: Author.

Handschin, L. (2012). Risk-based Equity Requirements: How Equity Rules for the Financial Sector can be Applied to the Real Economy. Journal of Corporate Law Studies, 12 (2), 255-293.

Istrefi, V. (2020). Corporate governance in Islamic financial institutions. Journal of Governance and Regulation/Volume, 9(2).

Kuran, T. (2011). The Long Divergence: How Islamic Held Back the Middle East. Princeton, NJ: Princeton University Press.

Nidaa Masood, N. (2006). The Islamization of Pakistan's Financial System: A Legal Analysis (PhD thesis,University of London, England). Available from uk.bl.ethos.485699

Nyazee, I.A.K. (2007). Corporations in Islam. Rawalpindi: Federal Law House.

Qur'ān 59:7.

Rasul, B. (2010). Lessons from Pakistan's Model. In Angelo M. Venardos (Ed.), Current Issues in Islamic Banking and Finance. Singapore, Singapore: World Scientific Publishing Co. Pte. Ltd.

Ross,S.A., Westerfield, R.W., \& Jordan, B.D. (2010). Fundamentals of Corporate Finance ( $9^{\text {th }}$ Ed.). New York, NY: McGraw-Hill.

Supreme Court of Pakistan (n.d). The Text of the Historic Judgement on Interest given by the Supreme Court of Pakistan (n.d). Retrieved from http://www.albalagh.net/Islamic_economics/riba_judgement.pdf

Usmani, M.M.T. (2004). An Introduction to Islamic Finance. Karachi: Maktaba Ma'Ariful Qur'an.

Venardos, A.M. (2010). Current Issues in Islamic Banking and Finance. Singapore, 
Singapore: World Scientific Publishing Co. Pte. Ltd.

Venardos, A.M. (2012). Islamic Banking and Finance in South-East Asia-Its

Development and Future ( $3^{\text {rd }}$ Ed.). Singapore, Singapore: World Scientific Publishing Co. Pte. Ltd.

Vogel, F.E., \& Hayes, S.L. (1998). Islamic Law and Finance: Religion, Risk, and Return.

The Hague: Kluwar Law International.

Von Pock, A. (2007). Strategic Management in Islamic Finance. Wiebaden, Germany: Deutscher Universitats-Verlag.

Warde, I. (2012). Status of the Global Islamic Finance Industry. In Craig R. Nethercott and David M. Eisenberg (Ed.), Islamic Finance: Law and Practice. Oxford, England: Oxford University Press. 